\title{
What Works on Economic Growth? Funds Efficiency or Growth Opportunities
}

\author{
Chiou-Rung Chen ${ }^{1, *}$, Chai-Liang Huang ${ }^{2}$, Feng-Hueih Huarng ${ }^{3}$ \\ ${ }^{1}$ Department of Educational Management, National Taipei University of Education, Taiwan \\ ${ }^{2}$ Department of Finance, National Chung Cheng University, Taiwan \\ ${ }^{3}$ Department of Business Administration, Southern Taiwan University, Taiwan
}

Copyright $\mathrm{C} 2016$ by authors, all rights reserved. Authors agree that this article remains permanently open access under the terms of the Creative Commons Attribution License 4.0 International License

\begin{abstract}
This study investigates the impacts of funds utilization efficiency and growth opportunities on the finance-growth nexus for 49 countries from 1960 to 2004. Results show that the funds utilization efficiency, both of assets and liability allocation efficiency, and growth opportunities are the predominant factors in the finance-growth nexus. Financial intermediaries who utilize funds efficiently and possess fine growth opportunities are capable of accelerating real economic growth. In contrast, financial intermediaries who utilize funds inefficiently and lack fine growth opportunities hinder economic growth. The result implies governments should formulate policies to improve funds utilization efficiency and growth opportunities rather than to just monotonically promote financial development or income levels. Furthermore, the predominance of funds utilization efficiency and growth opportunities in finance-growth nexus is more potent in developing countries than in developed countries. Finally, the results are robust to discontinuity caused by operation of European Monetary Unification (EMU), and to models subsuming stock market measures.
\end{abstract}

Keywords Economic Growth, Funds Efficiency, Growth Opportunities

JEL Codes: O4, G2, G1

\section{Introduction}

The deep economic recession followed by 2008 banking crisis has brought our attention to the relationship between banking development and economic growth. Financial intermediaries in an economy are expected to promote economic growth due to their role to alleviate information asymmetry and to efficiently transfer funds from depositors to firms. This assertion is advanced by Schumpeter (1912) firstly, and then developed and verified by a numerous theoretical $^{\mathbf{i}}$ and empirical studies ${ }^{\mathbf{i}}$ for a long time. However, it appears that more and more facts, both coming from empirical findings and real world phenomena, do not align with this opinion.

De Gregorio and Guidotti (1995), Demetriades and Hussein (1996), Deidda and Fattouh (2002), Rioja and Valev (2003), Shen and Lee (2006) find that finance may have distinct effects on economic growth at different income levels. Specifically, De Gregorio and Guidotti (1995) find that financial intermediaries exhibit a positive effect on long-run growth for middle- and low-income countries, though a negative effect for Latin American economies. They therefore argue that financial liberalization in an unstable economy will result in excessive lending and inefficient credit allocations, and thus, the inefficiency is likely to translate into a reduction of long-run growth. Deidda and Fattouh (2002), Rioja and Valev (2003) find financial intermediaries exhibit significantly positive effects on economic growth only in high-income countries, rather than in low-income countries. Further, Shen and Lee (2006) find that financial intermediaries do convey significantly negative effects on real growth, especially for economies with low-income levels and unsound regulation environments, such as shareholder protection mechanism, financial liberalization.

Also, Levine et al. (2000), Rioja and Valev (2004) and Chen (2008) find that financial intermediaries do not exhibit monotonically positive effects on economic growth for countries at different levels of financial development. Levine et al. (2000) and Rioja and Valev (2004) show that financial intermediaries displays stronger positive effects on economic growth in countries which have lower levels of financial intermediary development than those have higher levels. Moreover, Chen (2008) finds that financial intermediaries accelerate economic growth at low levels of financial intermediary development, but mitigate economic growth at high levels.

In summary, although so many theoretical models have well demonstrated that financial intermediaries boost 
economic growth by improving funds utilization efficiency, no empirical studies directly examine how the funds utilization efficiency accomplished by financial intermediaries affect the finance-growth nexus. The lack of direct examination of funds utilization efficiency's impacts on finance-growth nexus may not only cause biases to omit variables and doubtful empirical results, but also cannot explain what causes the varying effects of financial intermediaries on economic growth well.

Based on the theoretical literature and the empirical controversies over the finance-growth nexus, this study asserts that finance-growth nexus may not be monotonic. Specifically, only when financial intermediaries utilize funds efficiently and possess fine growth opportunities, they are capable of promoting economic growth. By constructing seven indicators to quantitatively evaluate the funds utilization efficiency and one indicator to measure the growth opportunities, this study is able to directly examine the impacts of funds utilization efficiency and growth opportunities on finance-growth nexus.

Firstly, this paper asserts that the funds utilization efficiency which financial intermediaries exhibit in an economy is a pivotal factor in the finance-growth nexus iii. If financial intermediaries keep too many funds and make too less loans, the funds inefficiency in financial intermediaries mitigates rather than accelerates economic growth. On the other hand, if financial intermediaries pursue high profits or high market shares and thus are engaged in highly risk-taking activities, such as lower loan criteria and make loans to firms with high default risk, they tend to make excessive loans to firms. The highly risk-taking behavior may increase the quantity of loan, but it makes funds utilization inefficient, and thus undermines the contribution of financial intermediaries to economic growth, and even be likely causes financial crisis to impede economic growth, rather than to promote economic growth ${ }^{\text {iv }}$. Therefore, there should be an optimal range of loans, given a fixed level of deposits. Only when financial intermediaries make loans within the optimal range, they efficiently transfer funds to demanders, neither making inefficient funds utilization nor engaging in highly risk-taking behavior, and thus are capable of accelerating economic growth.

Besides funds utilization efficiency, this paper also argues that growth opportunities are critical to the effects of financial intermediaries on economic growth. Given some fine growth opportunities, such as stable political environment and stable climate, investors are more confident of the economic prospect and thus are more willing to invest. Such willingness to invest would increase demand for loans and hence the quantity of loans. Also, other fine growth opportunities, such as good reputation, good customer relationship, and excellent expertise, may spur financial intermediaries to engage in less risky activities, and cause their creditors and/or the insurers to charge a lower default premium, which then induce them to further lower their risk-taking and utilize their funds more efficiently (Herring and Vankudre, 1987).
This paper samples 49 countries from 1960 to 2004 and finds that, rather than income levels or levels of financial development, it is funds utilization efficiency, both asset and liability allocation efficiency, and growth opportunities are the predominating factors in finance-growth nexus. And, this predominant effect is more potent in developing countries than in developed countries. Finally, the empirical results are robust to discontinuity caused by operation of European Monetary Unification (EMU), and to models subsuming stock market measure.

The paper is organized as follows. Section 2 reviews previous literature. Section 3 presents the methodology. Section 4 displays data description and empirical results. Section 5 concludes.

\section{Literature Review}

The functions of financial intermediaries on economic growth have been well demonstrated in a variety of theoretical and empirical models. Most of theoretical models stress real sectors benefit from financial sectors due to the higher quality of information, a lower cost of information which comprises the costs of screening and monitoring, a lower cost of transactions, and greater pooling and diversification of risks which include the liquidity risk and idiosyncratic risk. These benefits from financial sectors accelerate both of the marginal productivity and the allocated efficiency of physical capital, which in turn promotes productivity growth and economic growth.

Goldsmith (1969) argues that financial development enhances growth by improving the investment efficiency, i.e., the marginal productivity of physical capital. McKinnon, (1973), Shaw (1973) and Boyd and Prescott (1986) claim that financial intermediaries serve to provide information and thus mitigate information frictions and efficiently transfer funds from individual depositors to enterprises. The improvement of capital allocation efficiency thus raises the levels of savings and investments.

Greenwood and Jovanovic (1990) incorporate these opinions into the endogenous growth model. Their model claims that financial intermediaries perform two functions to boost economic growth. Firstly, by collecting and analyzing information, financial intermediaries efficiently fill funds to high-return projects, which in turn enhances allocated efficiency of physical capital and promotes real growth. The second is to pool risk across a great deal of investors. Both functions of insurance and the efficient allocation of capital supplied by financial intermediaries allow individuals to earn a safer and higher return, which thus increases the individual incentive to participate in capital market and further promote capital accumulation and efficiency.

Bencivenga and Smith (1995), Bose and Cothren (1997), Blackburn and Hung (1998) argue that adverse selection can either bring credit rationing and reduce the amount of funds filled into real investments, or increase the costs of 
monitoring and thus reduce the amount of investments. Therefore, the emergence of financial intermediaries contributes to reduction in information cost, which in turn accelerates capital accumulation and resources efficiency, and consequently fosters economic growth.

Other literature stresses financial intermediaries serve to pool liquidity risk and to diversify the idiosyncratic risk for individual households, and thus better the allocated efficiency of physical capital. Bencivenga and Smith (1991) assert that financial intermediaries serve to enhance liquidity and relieve idiosyncratic risk via risk diversification and to improve funds allocation efficiency, and thus highly contribute to productivity growth and economic growth. ${ }^{\mathrm{v}}$

Although so many theoretical models well demonstrate the effects of funds utilization efficiency and risk reduction performed by financial intermediaries on economic growth, evidences so far found by empirical studies are quite diverse.

To assess the finance-growth nexus, Levine and Zervos (1998) use cross-country regressions, Rousseau and Wachtel (2000) use a panel vector autoregression model (VAR), Arestis et al. (2001) use a vector autoregression model (VAR), and Beck and Levine (2004) apply a generalized method of moments (GMM) dynamic panel, and they all find that both financial intermediaries and stock markets help to boost economic growth. However, Arestis et al. (2001) find that financial intermediaries contribute more to economic growth than stock markets.

On the other hand, some empirical studies find possible nonlinear effects of financial development on economic growth. De Gregorio and Guidotti (1995), Demetriades and Hussein (1996), Deidda and Fattouh (2002), Rioja and Valev (2003), Shen and Lee (2006) find that finance may have different effects on economic growth at different income levels. De Gregorio and Guidotti (1995) show that financial intermediaries exhibit a positive effect on growth, especially for middle- and low-income countries among a sample of 98 countries from 1960 to 1985 . However, they find the relationship to be negative for 12 Latin American countries from 1950 to 1985 . They thus argue that financial liberalization in an unstable economy may result in excess lending and inefficient credit allocations. This inefficiency would likely translate into reduction of long-run growth.

Deidda and Fattouh (2002) use threshold panel models for 119 countries from 1960 to 1989 and find that financial intermediaries perform significantly positive effects on economic growth only in high-income countries. Shen and Lee (2006) employ several of methodologies, including ordinary least square (OLS), fix-effect panel, random-effect panel as well as conditional models for 48 countries from 1976 to 2001. They find that only stock markets exert positive effects on economic growth; in contrast, financial intermediaries mainly convey negative effects on real growth though the negative effects are relieved by financial liberalization, high-income levels and good shareholder protection.

Furthermore, Levine et al. (2000), Rioja and Valev (2004) and Chen (2008) find that financial intermediaries do not exhibit monotonically positive effects on economic growth for countries at varying levels of financial development. Levine et al. (2000) apply both cross-country regressions and GMM dynamic panel regressions for 71 countries from 1960 to 1995 and find that legal and accounting reforms accelerate financial development, thus promote economic growth. Rioja and Valev (2004) employs threshold panel regressions for 74 countries from 1960 to 1995 and find that financial intermediaries exert stronger positive effects on economic growth at the middle levels of financial intermediary development, and weaker positive effects on economic growth at the high levels.

Finally, Chang et al. (2010) follows La Porta et al. (2002) to reexamine the finance-growth nexus in China and find consistent results with La Porta et al. (2002). Inefficient fund reallocation caused by a high level of government ownership in Chinese banks is associated with lower economic growth.

In summary, this paper, which is basing on the inference of theoretical literature and controversies of empirical literature over the finance-growth nexus, asserts that only financial intermediaries who utilize funds efficiently and possess fine growth opportunities are capable of promoting economic growth. By establishing seven indicators to quantitatively evaluate the funds utilization efficiency and one indicator to measure growth opportunities, this paper is able to directly examine how the funds utilization efficiency affect the finance-growth nexus and explain the controversies over previous empirical findings.

\section{Methodology}

This paper uses the data of 49 countries from 1960 to 2004 to examine whether funds utilization efficiency and growth opportunities impact the effects of financial intermediaries on economic growth. Appendix Table A1 lists the sample countries in this paper ${ }^{\mathrm{vi}}$.

The fixed-effect panel model employed in this paper is as follows.

$$
\begin{aligned}
& E G_{i, t}=\mu_{i}+\beta_{1} \cdot F I_{i, t}+\beta_{2} \cdot E F F_{i t} \cdot F I_{i, t} \\
& +\beta_{3} \cdot O P P_{i t} \cdot F I_{i, t}+\gamma \cdot X_{i, t}+e_{i, t}
\end{aligned}
$$

where the subscript $i$ denotes the individual country and the subscript $t$ denotes time.

$E G_{i, t}$ denotes economic growth and is measured with growth rate of real GDP per capita. $F I_{i, t}$ denotes the levels of financial intermediary development and is measured by PRIVY_ALL in this study ${ }^{\text {vii }}$. PRIVY_ALL is private loans delivered by deposit monetary financial intermediaries and other financial institutions over GDP. It is a broader measure because it comprises the private loans made by not only the deposit monetary financial intermediaries but also other financial institutions. Thus PRIVY ALL assesses the function of loan supply of overall financial intermediation to private enterprises. 
$E F F_{i, t}$ represents funds utilization efficiency. This paper develops seven indicators to accurately measure the funds utilization efficiency and each indicator is employed in the model respectively. The first indicator is $\mathrm{PL}_{\mathrm{fi}} \mathrm{DD}$, which is the ratio of private loans delivered by deposit monetary financial intermediaries and other financial institutions to total domestic deposits received by financial intermediaries. $\mathrm{PL}_{\mathrm{fi}}$ DD represents the proportion of funds transferred by financial intermediaries to private sectors over total funds which they received from domestic depositors. This paper argues that only when financial intermediaries use their funds efficiently and thus this ratio fall within an optimal range, financial intermediaries are contributive to economic growth.

The argument makes sense since a small ratio indicates insufficient funds transferred by financial intermediaries to firms relative to funds which they receive from depositors. The inefficient funds utilization of financial intermediaries are expected to be helpless to and even impede economic growth rather than promote economic growth. On the other hand, if the ratio is too high, that may signify that financial intermediaries take high-risk activities to pursue high profit or high market shares, such as lower loan criteria to make loans to debtors with inferior credit. To the extremity, a ratio which is beyond 1.0 represents that besides the deposits, the sources of loans comprise foreign liabilities and market borrowing. That implies that the financial intermediaries are engaged in excessive financial leverage and encounter high liquidity risk and interest rate risk. The highly risk-taking financial intermediaries utilize funds inefficiently and incur high degree of default risk and consequently, are much less likely to accelerate economic growth and even hinder economic growth. Accordingly, this paper argues that only when the ratio of $\mathrm{PL}_{\mathrm{fi}} \mathrm{DD}$ falls within the optimal range, that is, neither too high nor too low, financial intermediaries achieve efficient funds utilization and are capable of advancing economic growth.

In order to take central banks into account, this study establishes the second indicator, PL_DD. PL_DD includes the private loans delivered by central banks and is the ratio of private loans delivered by financial intermediaries and central banks to total domestic deposits received by financial intermediaries. The third is TL DD and is the ratio of total loans to total domestic deposits received by financial intermediaries. Similarly, the forth indicator, PL TF, is the ratio of private loans delivered by financial intermediaries and central bank to total funds, which include domestic deposits received by financial intermediaries and foreign liabilities.

Moreover, this paper further decomposes the first indicator of funds utilization efficiency, $\mathrm{PL}_{\mathrm{fi}} \mathrm{DD}$, and develops two indicators for asset allocation efficiency and one indicator for liability allocation efficiency. Mathematically, the indicator of funds utilization efficiency, $\mathrm{PL}_{\mathrm{fi}} \mathrm{DD}$, can be decomposed as follows:

$$
\begin{aligned}
P L_{f i}{ }_{-} D D & =P L_{f i \_} P L \times P L_{-} T L \times T L_{-} D D \\
& =P L_{f i-} P L \times P L_{-} T F \times T F_{-} D D
\end{aligned}
$$

$\mathrm{PL}_{\mathrm{fi}} \mathrm{PL}$ in formula (2), one of the indicators for asset allocation efficiency, measures the share of private loans delivered by financial intermediaries over total private loans. Since central bank in an economy usually takes responsibility to economic policies and may be expected to engage in less efficient funds utilization, this measure may reflect the degree of asset allocation efficiency in the economy. PL_TL, the other indicator for asset allocation efficiency, denotes the loan share of private loans to total loans. Private loans are thought of as the more efficient loans relative to non-private loans, and thus this indicator also demonstrates the degree of asset allocation efficiency in an economy. TF_DD, the indicator for liability allocation efficiency, is total liabilities over domestic deposits. Domestic deposits are recognized as a less risky source of funds than foreign liabilities, though with abundant funds available, financial intermediaries may possess higher liquidity and are able to utilize funds flexibly. Consequently, they are capable of accelerating economic growth. Thus, this indicator assesses the liability allocation efficiency, which is the efficiency of funds source.

As mentioned above, formula (2) can be expressed as follows.

$$
\begin{gathered}
\text { Total Efficiency }=\text { Asset Allocation Efficiency } \times \text { Fund } \\
\text { Utilization Efficiency } \times \\
\times \text { Liability Allocation Efficiency }
\end{gathered}
$$

Since the indicator of funds utilization efficiency, $\mathrm{PL}_{\mathrm{fi}} \mathrm{DD}$, is the combination of asset allocation efficiency, liability allocation efficiency and funds utilization efficiency, it can be defined as the total funds efficiency.

Furthermore, OPP in formula (1) denotes growth opportunities for financial intermediaries and is measured by net growth rate of loan (NLG). This measure makes sense since growth opportunities which financial intermediaries face not only affects their loan demand, but also affects their willingness of risk-taking and consequently, affects the effects of financial intermediaries on economic growth.

Given fine growth opportunities, such as stable political environment and stable climate, investors are more confident of the economic perspectives and thus are more willing to engage in investment. Accordingly, investors' engagement in investment accelerates loan demand and loan grows quickly. Also, fine growth opportunities, such as sound reputation, good customer relationship, and excellent expertise may spur financial intermediaries to engage in less risky activities, and cause their creditors and/or the insurers to charge a lower default premium, and that induce them to further lower their risk-taking and utilize their funds more efficiently (Herring and Vankudre, 1987). 
To erase the proportion of loan growth caused by the pressure of a great amount of deposits, rather than induced by growth opportunities facing financial intermediaries, this paper develops the dummy variable, NLG, which is the difference in growth rate between loan and deposit. Since this paper argues that only financial intermediaries possess fine growth opportunities can boost economic growth, OPP is equal to one if NLG is greater than zero, otherwise, OPP is equal to zero.

In addition, $X_{i, t}$ in formula (1) represents the control variables in the conditional information set of the models and is to control other potential determinants of economic growth. They are the logarithm of initial level of real per capita GDP (INIY), the logarithm of initial value of secondary school enrollment rate (INIH), the ratio of government consumption expenditures to GDP (GOVY), the openness to trade (the ratio of sum of export and import) to GDP (EXIMY), the inflation rate (CPIG), and the financial crisis (CRISIS).

INIY controls the convergence effect implied in economic growth model. INIH controls the human capital accumulation effect. GOVY, EXIMY, and CPIG control macroeconomic policies in the country. Finally, since previous studies, such as Shen and Lee (2006), Ranciere et al. (2006), find that bank crises significantly impede economic growth, CRISIS is also added.

The coefficients of $\mu_{i}$ capture the individual specific fixed effects. The coefficient of $\beta_{1}$ reflects the impacts of financial intermediaries, who have neither efficient fund utilization nor growth opportunities, on economic growth. The coefficient of $\beta_{2}$ reflects the impacts of financial intermediaries, who utilize funds efficiently, on economic growth. The coefficient of $\beta_{3}$ reflects the impacts of financial intermediaries, who possess growth opportunities, on economic growth. Finally, the coefficients of $\gamma$ reflect the impact of each control variable on economic growth, respectively.

Moreover, since lots of theoretical and empirical studies have documented the contribution of stock market on economic growth ${ }^{\text {viii }}$, this paper adds the degree of stock market development into the empirical model in formula (1) as robustness tests and the empirical model is expressed as follows:

$$
\begin{aligned}
& E G_{i, t}=\mu_{i}+\beta_{1} \cdot F I_{i, t}+\beta_{2} \cdot E F F_{i t} \cdot F I_{i, t}+\beta_{3} \cdot O P P_{i t} \cdot F I_{i, t} \\
& +\delta \cdot S T O C K_{i t}+\gamma \cdot X_{i, t}+e_{i, t}
\end{aligned}
$$

STOCK $_{i, t}$ denotes the degree of stock market development and is the trading value of stock market over stock market capitalization.

\section{Empirical Results}

\subsection{Data Description}

Table 1 summarizes the definitions and sources of all variables. The data required to calculate economic growth are from Penn World Table, version 6.2 (PWT6.2). The PWT6.2 provides consistent denomination of account data based on benchmark data from the international comparison of prices program (ICP), and thus can offer comparable and consistent level data. The data of all financial intermediaries' indicators and control variables, except to the initial value of secondary-school enrollment rate, are all available from International Financial Statistics (IFS) published by International Monetary Fund. The data of the initial value of secondary-school enrollment rate is from World Development Indicators (WDI). The data of stock market measures are all available from Global Stock Markets Factbook and Emerging Stock Markets Factbook, both published by Standard \& Poor's, a division of the McGraw-Hill Companies, Inc.. Table 2 presents the summary statistics of all variables. 
Table 1. Definitions and Sources of Variables

\begin{tabular}{|c|c|c|c|}
\hline Type of variable & Variable name & Definition & Source \\
\hline $\begin{array}{c}\text { Financial } \\
\text { intermediaries }(\mathrm{FI})\end{array}$ & PRIVY_ALL & $\begin{array}{c}\text { Private loans delivered by deposit monetary financial intermediaries } \\
\text { and other financial institutions / GDP }\end{array}$ & IFS \\
\hline \multirow{6}{*}{$\begin{array}{l}\text { Fund Utilization } \\
\text { Efficiency (EFF) }\end{array}$} & $\mathrm{PL}_{\mathrm{fi}} \mathrm{DD}$ & $\begin{array}{c}\text { Private loans delivered by deposit monetary financial intermediaries } \\
\text { and other financial institutions / Total deposits received by financial } \\
\text { intermediaries }\end{array}$ & IFS \\
\hline & PL_DD & $\begin{array}{c}\text { Private loans delivered by central banks and financial intermediaries / } \\
\text { Total deposits received by financial intermediaries }\end{array}$ & IFS \\
\hline & TL_DD & $\begin{array}{c}\text { Total Loans delivered by financial intermediaries /Total deposits } \\
\text { received by financial intermediaries }\end{array}$ & IFS \\
\hline & PL_TF & $\begin{array}{c}\text { Private loans delivered by central banks and financial } \\
\text { intermediaries / Total deposits received by financial } \\
\text { intermediaries and foreign liabilities } \\
\end{array}$ & IFS \\
\hline & PL_TL & $\begin{array}{c}\text { Private loans delivered by central banks and financial intermediaries / } \\
\text { Total Loans delivered by financial intermediaries }\end{array}$ & IFS \\
\hline & TF_DD & $\begin{array}{l}\text { Total deposits received by financial intermediaries and foreign } \\
\text { liabilities / Total deposits received by financial intermediaries }\end{array}$ & IFS \\
\hline $\begin{array}{l}\text { Growth Opportunities } \\
\text { (OPP) }\end{array}$ & NLG & Growth rate of total loans- Growth rate of total deposits & IFS \\
\hline \multirow{2}{*}{ Control Variables } & INIY & Logarithm vale of real per capita GDP in 1960,1980 & PWT62 \\
\hline & $\mathrm{INIH}$ & Logarithm vale of secondary school enrollment rate in 1960,1980 & WDI \\
\hline Stock Market & STOCK & Trading value of stock market / Stock market capitalization & GSMF, ESMF \\
\hline
\end{tabular}

Note: PWT62 is Penn World Table, version 6.2; IFS is International Financial Statistics published by International Monetary Fund; WDI is World Development Indicators published by World Bank; GSMFand ESMF are Global Stock Markets Factbook and Emerging Stock Markets Factbook, respectively; PIM is perpetual inventory method.

Table 2. Summary Statistics

\begin{tabular}{|c|c|c|c|c|c|}
\hline Variables & Observation & Mean & Std. Dev. & Minimum & Maximum \\
\hline EG & 2205 & 1.0256 & 0.0122 & 0.9988 & 1.0585 \\
\hline FI & 2169 & 0.5598 & 0.3343 & 0.1153 & 1.4170 \\
\hline PL_f_DD & 2159 & 0.8185 & 0.3379 & 0.2098 & 3.3118 \\
\hline PL_DD & 2171 & 0.8286 & 0.3491 & 0.0000 & 3.3118 \\
\hline TL_DD & 2151 & 1.1214 & 0.4368 & -0.4254 & 6.2313 \\
\hline PL_TF & 2094 & 0.6822 & 0.2727 & 0.0337 & 3.1396 \\
\hline PL_f_PL & 2160 & 0.9850 & 0.0628 & 0.4417 & 1.2483 \\
\hline PL_TL & 2141 & 0.7574 & 0.3853 & -4.5159 & 4.7065 \\
\hline TF_DD & 2094 & 0.8322 & 0.1761 & 0.0542 & 1.0000 \\
\hline OPP & 2144 & 0.0286 & 0.8234 & -7.2164 & 34.4429 \\
\hline INIY & 2160 & 8.3751 & 0.8674 & 6.6856 & 9.6326 \\
\hline INIH & 2205 & 3.2588 & 0.8211 & 0.6931 & 4.4543 \\
\hline GOVY & 2203 & 0.1514 & 0.0485 & 0.0681 & 0.3101 \\
\hline EXIMY & 2203 & 0.6357 & 0.4455 & 0.1579 & 2.7320 \\
\hline CPIG & 2189 & 0.2685 & 0.6301 & 0.0276 & 2.9481 \\
\hline STOCK & 1244 & 0.4312 & 0.5007 & 0.0136 & 3.1950 \\
\hline
\end{tabular}




\subsection{Empirical Results}

This study empirically investigates whether funds utilization efficiency and growth opportunities of financial intermediaries influence the effects of financial intermediaries on economic growth. As the sample in this study includes the eleven member countries of European Monetary Unification (EMU), which adopt the euro as single official currency since January 1, 1999, the financial reports of all financial institutions, especially the banks, are reformulated in the new currency. This leads a discontinuity of bank data and may cause biased estimation. In order to take the discontinuity problem and potential biases into account, this study employs data from 1960 to 1999 to be our studying period firstly, and further extends to 2004 as evidence for robustness.

\subsubsection{Basic Models}

To explore the impacts of the funds utilization efficiency and growth opportunities for financial intermediaries on finance-growth nexus, seven indicators of funds utilization efficiency are established and set as dummy variables in a series of regression models, respectively. Table 3 shows the empirical results of these models from 1960 to 1999. Model 1 in Table 3 shows that the coefficient of $\mathrm{PL}_{\mathrm{fi}} \mathrm{DD}$ FI, are positive and strongly significant when $\mathrm{PL}_{\mathrm{fi}} \mathrm{DD}$ falls into the rage of 51 to $61 \%$.

This suggests that funds utilization efficiency indeed plays a pivotal role in the effects of deposit monetary financial intermediaries on economic growth. Only when financial intermediaries use their funds efficiently and thus $\mathrm{PL}_{\mathrm{fi}} \mathrm{DD}$ falls into the optimal range, they are beneficial to economic growth. Moreover, Table 3 shows that the coefficient of OPP*FI, are positive and strongly significant when NG is greater than one ${ }^{\mathrm{ix}}$. In other words, growth opportunities faced by financial intermediaries does evidently influence the impact of deposit monetary financial intermediaries on economic growth. Only financial intermediaries possess fine growth opportunities can boost economic growth.

Since the coefficients of EFF*FI and OPP*FI, which are $\beta_{2}$ and $\beta_{3}$, respectively, represent the variation caused by funds utilization efficiency and growth opportunities in the financial intermediaries' effects on economic growth. The total impact of funds utilization efficiency and growth opportunities is the sum of $\beta_{1}, \beta_{2}$, and $\beta_{3}$, i.e., $\beta_{1}+\beta_{2}+\beta_{3}$. If $\beta_{1}+\beta_{2}+\beta_{3}>0$, the total impact is positive. If $\beta_{1}+\beta_{2}+\beta_{3}<0$, the total impact on the economy is negative. Model 1 in Table 3 shows, $\beta_{1}+\beta_{2}+\beta_{3}$ is positive. The results prove that both funds utilization efficiency and growth opportunities are crucial to the effects of financial intermediaries on economic growth. Only financial intermediaries who possess good growth opportunities and utilize their funds efficiently are capable of fostering economic growth.

Model 2 in Table 3 shows results consistent with the results of Model 1. Financial intermediaries accelerate economic growth when PL DD falls into the optimal range of 50 to $61 \%$. Similarly, Model 3 and Model 4 in Table 3 display that when TL_DD is within 56 to $84 \%$ and PL_TF is within 45 to $55 \%$, financial intermediaries are contributive to economic growth. In addition, all of these three models find that financial intermediaries possess growth opportunities do promote economic growth. And all of them show that the sum of $\beta_{1}, \beta_{2}$, and $\beta_{3}$ is positive.

Model 5 through Model 11 in Table 3 present the impacts of asset allocation efficiency and liability allocation efficiency of finance-growth nexus. The coefficients of $\mathrm{PL}_{\mathrm{fi}} \mathrm{PL} * \mathrm{FI}$ are all strongly significant and positive in Model 5 through Model 11 of Table 3 when $\mathrm{PL}_{\mathrm{fi}}$ PL falls within 89 to $96 \%$. The results demonstrate that financial intermediaries in an economy where the intermediaries deliver higher share of private loans than central banks have better function on economic growth. These results are quite consistent with the findings in Shen and Lee (2006), and Change et al. (2010), which state that financial liberalization and reform enhance asset allocation efficiency and thus are contributive to the positive relationship between finance intermediation and economic growth. Similarly, the coefficients of PL_TL*FI are all strongly significant and positive in Model 6 and Model 10 when PL_TL falls within about 60 to 99\%. The majority status of private loan in total loans reflects the high level of asset allocation efficiency, and thus the results further exhibit that asset allocation efficiency does significantly influence the finance-growth nexus. Financial intermediaries are constructive to economic growth only when they have high level of asset allocation efficiency. On the other hand, the coefficients of TF_DD*FI are all strongly significant and positive in Model $\overline{8}$ and Model 11 when TF_DD falls within 2.2 to 2.8 . Such result suggests that, with plentiful funds available, financial intermediaries possess higher liquidity and are able to utilize funds flexibly. Consequently, they are capable of boosting economic growth.

Moreover, the coefficients of OPP*FI are significantly positive in Model 5 through Model 11 of Table 3. The results further confirm that financial intermediaries facing good growth opportunities are contributive to economic growth. Furthermore, the results that the sum of betas is positive in Model 5 through Model 11 of Table 3 demonstrate both funds utilization efficiency and growth opportunities are critical to the effects of financial intermediaries on economic growth.

Finally, all models in Table 3 show that bank crises have significantly negative impacts on economic growth, and such finding is consistent with Shen and Lee (2006) and Ranciere et al.(2006).

\subsubsection{Robustness Tests}

Since eleven member countries of European Monetary Unification (EMU) are included in the sample of this study and they have adopted Euros as their single official currency on January 1, 1999. This study uses data from 1960 to 1999 as basic sample period in order to take the discontinuity of data into consideration and to provide robustness, and further extends to 2004 to reexamine the models. Results in Table 4 
demonstrate that almost all the results are robust to the extended sample period. The results further confirm the hypothesis advanced by this study that funds utilization efficiency and growth opportunities do play critical role in the effects of financial intermediaries on economic growth.

Furthermore, some previous studies, such as De Gregorio and Guidotti (1995), Demetriades and Hussein (1996), Deidda and Fattouh (2002), Rioja and Valev (2003), find that finance may have different effects on economic growth at different levels of income and financial development. To take the variation in levels of income and financial development into account, this study further splits sample countries into two subsamples of the developed and developing countries.

Table 5 and Table 6 exhibit the results for developed counties and developing countries, respectively. Results in Table 5 and Table 6 show that the coefficients of funds utilization efficiency $\left(\mathrm{EFF}^{*} \mathrm{FI}\right)$ and growth opportunities (OPP*FI) are significantly positive for both developed and developing countries. The results further manifest that regardless of income levels and levels of financial development being controlled or not, funds utilization efficiency and the growth opportunities are the predominant factors in the effects of financial intermediaries on economic growth for both developed and developing countries.

Specifically, although the results for developed and developing countries are similar, the magnitude of coefficients in both tables is slightly different. Most of the coefficients of funds utilization efficiency and growth opportunities are more positive for developing countries in Table 6 than for developed countries in Table 5. In addition, the coefficients of financial development (FI) are more negative for the developing countries in Table 6 than for developed countries in Table 5. These results suggest that relative to developed countries, financial intermediaries in developing countries exert more positive influence on economic growth if they utilize funds efficiently and encounter growth opportunities. In contrast, intermediaries who utilize funds inefficiently and lack growth opportunities impact economic growth in developing countries more negatively than in developed countries. From this, it could be concluded that funds utilization efficiency and growth opportunities are more crucial to finance-growth nexus in developing countries than in developed countries. Variation in finance-growth nexus caused by funds utilization efficiency and growth opportunities are greater in developing countries than in developed countries. The findings in this study are consistent with and also explain previous studies that financial intermediaries in an immature environment, such as an unsound legal and accounting system, may cause inefficient funds allocation and highly risk-taking, and consequently hinder instead of accelerate economic growth (De Gregorio and Guidotti, 1995; Levine et al., 2000; Chang et al., 2010).

Finally, this study includes the stock market variable, STOCK, into regression models and the results are shown in Table 7. Regressions with the addition of STOCK display robust results to previous ones. The coefficients of funds utilization efficiency and growth opportunities remain positive and significant. The coefficients for funds utilization inefficiency and the absence of growth opportunities are still significantly negative. The total impacts on economic growth caused by efficient financial intermediaries encountering fine growth opportunities, $\left(\beta_{1}+\beta_{2}+\beta_{3}\right)$, remain positive. Furthermore, consistent with previous literature, the impact of STOCK is positive and significant in most of regressions (Beck and Levine, 2004; Shen and Lee, 2006; Chen, 2008). 
Table 3. Basic Models for Effects of Fund Utilization Efficiency And Growth Opportunities on Finance-growth Nexus

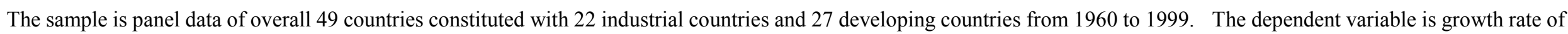

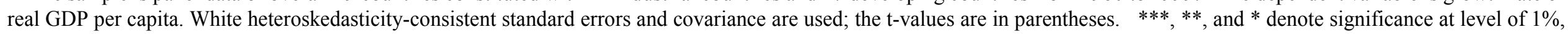
$5 \%$, and $10 \%$, respectively.

\begin{tabular}{|c|c|c|c|c|c|c|c|c|c|c|c|}
\hline Model & 1 & 2 & 3 & 4 & 5 & 6 & 7 & 8 & 9 & 10 & 11 \\
\hline \multirow[t]{2}{*}{ INIY } & -0.004 & -0.005 & -0.006 & -0.004 & -0.004 & -0.006 & -0.006 & -0.004 & -0.004 & -0.006 & -0.004 \\
\hline & $(0.00)$ & $(0.00)$ & $(0.00)$ & $(0.00)$ & $(0.00)$ & $(0.00)$ & $(0.00)$ & $(0.00)$ & $(0.00)$ & $(0.00)$ & $(0.00)$ \\
\hline \multirow[t]{2}{*}{ INIH } & -0.011 & -0.012 & -0.012 & -0.011 & -0.013 & -0.012 & -0.012 & -0.011 & -0.011 & -0.012 & -0.011 \\
\hline & $(0.00)$ & $(0.00)$ & $(0.00)$ & $(0.00)$ & $(0.00)$ & $(0.00)$ & $(0.00)$ & $(0.00)$ & $(0.00)$ & $(0.00)$ & $(0.00)$ \\
\hline \multirow[t]{2}{*}{ GOVY } & -0.215 & -0.208 & -0.201 & -0.213 & -0.209 & -0.198 & -0.209 & -0.208 & -0.21 & -0.189 & -0.21 \\
\hline & $(-7.028)^{* * *}$ & $(-6.968) * * *$ & $(-6.689)^{* * *}$ & $(-6.932)^{* * *}$ & $(-6.966) * * *$ & $(-6.578) * * *$ & $(-6.907) * * *$ & $(-6.756)^{* * *}$ & $(-6.837)^{* * *}$ & $(-6.204)^{* * *}$ & $(-6.806)^{* * *}$ \\
\hline \multirow[t]{2}{*}{ EXIMY } & 0.005 & 0.004 & 0.004 & 0.002 & 0.0030 & 0.002 & 0.006 & 0.001 & 0 & 0.003 & 0.001 \\
\hline & $(0.703)$ & $(0.611)$ & $(0.529)$ & $(0.373)$ & $(0.409)$ & $(0.314)$ & $(0.894)$ & $(0.164)$ & $(0.019)$ & $(0.387)$ & $(0.208)$ \\
\hline \multirow[t]{2}{*}{ CPIG } & -0.002 & -0.002 & -0.002 & -0.002 & -0.002 & -0.002 & -0.002 & -0.002 & -0.002 & -0.002 & -0.002 \\
\hline & $(-2.708) * * *$ & $(-2.716) * * *$ & $(-2.756)^{* * *}$ & $(-2.716)^{* * *}$ & $(-2.713) * * *$ & $(-2.733) * * *$ & $(-2.725) * * *$ & $(-2.702) * * *$ & $(-2.721)^{* * *}$ & $(-2.741)^{* * *}$ & $(-2.700) * * *$ \\
\hline \multirow[t]{2}{*}{ CRISIS } & -0.023 & -0.022 & -0.021 & -0.021 & -0.022 & -0.022 & -0.022 & -0.022 & -0.022 & -0.021 & -0.022 \\
\hline & $(-7.040)^{* * *}$ & $(-6.952)^{* * *}$ & $(-6.717)^{* * *}$ & $(-6.688)^{* * *}$ & $(-7.107)^{* * *}$ & $(-6.994) * * *$ & $(-7.033) * * *$ & $(-6.875)^{* * *}$ & $(-6.878)^{* * *}$ & $(-6.891)^{* * *}$ & $(-6.884) * * *$ \\
\hline \multirow[t]{2}{*}{ FI } & -0.023 & -0.02 & -0.022 & -0.023 & -0.021 & -0.034 & -0.023 & -0.026 & -0.024 & -0.033 & -0.025 \\
\hline & $(-4.926)^{* * *}$ & $(-4.243)^{* * *}$ & $(-4.627)^{* * *}$ & $(-4.822)^{* * *}$ & $(-4.559) * * *$ & $(-4.913)^{* * *}$ & $(-4.854) * * *$ & $(-5.366)^{* * *}$ & $(-5.196)^{* * *}$ & $(-4.840)^{* * *}$ & $(-5.127)^{* * *}$ \\
\hline \multirow[t]{2}{*}{$\mathrm{PL}_{\mathrm{fi} \_} \mathrm{DD} * \mathrm{FI}$} & 0.014 & & & & & & & & & & \\
\hline & $(2.830)^{* * *}$ & & & & & & & & & & \\
\hline \multirow[t]{2}{*}{ PL_DD*FI } & & 0.027 & & & 0.027 & & & & & & \\
\hline & & $(2.580)^{* * *}$ & & & $(2.136) * *$ & & & & & & \\
\hline \multirow[t]{2}{*}{ TL_DD*FI } & & & 0.019 & & & & 0.023 & & & 0.035 & \\
\hline & & & $(2.794)^{* * *}$ & & & & $(1.864)^{*}$ & & & $(3.646)^{* * *}$ & \\
\hline \multirow[t]{2}{*}{ PL_TF*FI } & & & & 0.025 & & & & & 0.037 & & 0.038 \\
\hline & & & & $(4.376)^{* * *}$ & & & & & $(4.219)^{* * *}$ & & $(2.724)^{* * *}$ \\
\hline \multirow{2}{*}{$\mathrm{PL}_{\mathrm{f} i-} \mathrm{PL} * \mathrm{FI}$} & & & & & 0.028 & 0.038 & 0.067 & 0.038 & 0.015 & 0.018 & 0.017 \\
\hline & & & & & $(2.543)^{* *}$ & $(4.324)^{* * *}$ & $(2.315)^{* *}$ & $(4.255)^{* * *}$ & $(2.683)^{* * *}$ & $(2.446)^{* *}$ & $(2.847)^{* * *}$ \\
\hline \multirow[t]{2}{*}{ PL_TL*FI } & & & & & & 0.011 & & & & 0.011 & \\
\hline & & & & & & $(2.169)^{* *}$ & & & & $(2.214)^{* *}$ & \\
\hline \multirow[t]{2}{*}{ TF_DD*FI } & & & & & & & & 0.026 & & & 0.015 \\
\hline & & & & & & & & $(4.923)^{* * *}$ & & & $(2.494)^{* *}$ \\
\hline \multirow[t]{2}{*}{ OPP*FI } & 0.014 & 0.013 & 0.013 & 0.015 & 0.013 & 0.013 & 0.013 & 0.014 & 0.014 & 0.013 & 0.014 \\
\hline & $(5.651)^{* * *}$ & $(5.381)^{* * *}$ & $(5.448)^{* * *}$ & $(5.848)^{* * *}$ & $(5.208)^{* * *}$ & $(5.428)^{* * * *}$ & $(5.213)^{* * *}$ & $(5.565)^{* * *}$ & $(5.516)^{* * *}$ & $(5.319)^{* * *}$ & $(5.727)^{* * *}$ \\
\hline $\mathrm{R}^{2}$-adj & 0.191 & 0.190 & 0.191 & 0.196 & 0.193 & 0.198 & 0.191 & 0.199 & 0.200 & 0.198 & 0.199 \\
\hline Obs & 1645 & 1705 & 1698 & 1645 & 1702 & 1698 & 1698 & 1645 & 1645 & 1698 & 1645 \\
\hline
\end{tabular}


Table 4. Robustness Tests with Extend Sample Period of 1960-2004

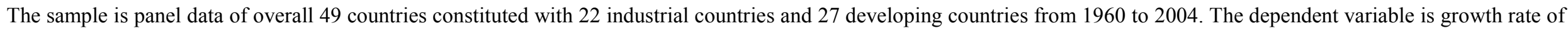

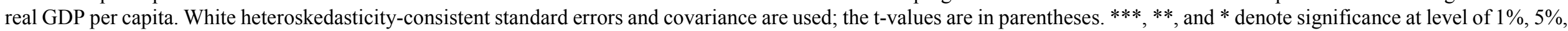
and $10 \%$, respectively.

\begin{tabular}{|c|c|c|c|c|c|c|c|c|c|c|c|}
\hline Model & 1 & 2 & 3 & 4 & 5 & 6 & 7 & 8 & 9 & 10 & 11 \\
\hline \multirow[t]{2}{*}{ INIY } & -0.005 & -0.005 & -0.005 & -0.005 & -0.005 & -0.005 & -0.005 & -0.005 & -0.005 & -0.005 & -0.005 \\
\hline & $(0.00)$ & $(0.00)$ & $(0.00)$ & $(0.00)$ & $(0.00)$ & $(0.00)$ & $(0.00)$ & $(0.00)$ & $(0.00)$ & $(0.00)$ & $(0.00)$ \\
\hline \multirow[t]{2}{*}{ INIH } & 0.004 & 0.003 & 0.001 & 0.004 & 0.002 & 0.001 & 0.001 & 0.004 & 0.004 & 0.001 & 0.004 \\
\hline & $(0.00)$ & $(0.00)$ & $(0.00)$ & $(0.00)$ & $(0.00)$ & $(0.00)$ & $(0.00)$ & $(0.00)$ & $(0.00)$ & $(0.00)$ & $(0.00)$ \\
\hline \multirow[t]{2}{*}{ GOVY } & -0.22 & -0.214 & -0.214 & -0.218 & -0.216 & -0.213 & -0.217 & -0.219 & -0.22 & -0.211 & -0.218 \\
\hline & $(-7.633)^{* * *}$ & $(-7.628)^{* * *}$ & $(-7.589)^{* * *}$ & $(-7.546)^{* * *}$ & $(-7.671)^{* * *}$ & $(-7.512)^{* * *}$ & $(-7.652)^{* * *}$ & $(-7.545)^{* * *}$ & $(-7.620)^{* * *}$ & $(-7.449)^{* * *}$ & $(-7.533)^{* * *}$ \\
\hline \multirow[t]{2}{*}{ EXIMY } & 0.006 & 0.005 & 0.006 & 0.004 & 0.005 & 0.006 & 0.008 & 0.005 & 0.004 & 0.006 & 0.005 \\
\hline & $(0.971)$ & $(0.879)$ & $(0.963)$ & $(0.734)$ & $(0.785)$ & $(0.942)$ & $(1.249)$ & $(0.799)$ & $(0.684)$ & $(1.002)$ & $(0.780)$ \\
\hline \multirow[t]{2}{*}{ CPIG } & -0.002 & -0.002 & -0.002 & -0.002 & -0.002 & -0.002 & -0.002 & -0.002 & -0.002 & -0.002 & -0.002 \\
\hline & $(-2.747) * * *$ & $(-2.756)^{* * *}$ & $(-2.763)^{* * *}$ & $(-2.756)^{* * *}$ & $(-2.751)^{* * *}$ & $(-2.762)^{* * *}$ & $(-2.760) * * *$ & $(-2.742)^{* * *}$ & $(-2.754)^{* * *}$ & $(-2.758)^{* * *}$ & $(-2.744)^{* * *}$ \\
\hline \multirow[t]{2}{*}{ CRISIS } & -0.022 & -0.021 & -0.02 & -0.021 & -0.022 & -0.021 & -0.021 & -0.022 & -0.021 & -0.021 & -0.022 \\
\hline & $(-6.926)^{* * *}$ & $(-6.837)^{* * *}$ & $(-6.667) * * *$ & $(-6.645)^{* * *}$ & $(-7.010)^{* * *}$ & $(-6.957)^{* * *}$ & $(-6.938) * * *$ & $(-6.857)^{* * *}$ & $(-6.886)^{* * *}$ & $(-6.874)^{* * *}$ & $(-6.814) * * *$ \\
\hline \multirow[t]{2}{*}{ FI } & -0.022 & -0.019 & -0.021 & -0.022 & -0.02 & -0.029 & -0.021 & -0.023 & -0.022 & -0.028 & -0.023 \\
\hline & $(-5.712)^{* * *}$ & $(-5.163)^{* * *}$ & $(-5.583)^{* * *}$ & $(-5.752)^{* * *}$ & $(-5.339)^{* * *}$ & $(-4.874)^{* * *}$ & $(-5.619)^{* * *}$ & $(-5.872)^{* * *}$ & $(-5.798)^{* * *}$ & $(-4.876)^{* * *}$ & $(-5.853)^{* * *}$ \\
\hline \multirow[t]{2}{*}{$\mathrm{PL}_{\mathrm{fi} \_\mathrm{DD}}$ FI } & 0.012 & & & & & & & & & & \\
\hline & $(2.626)^{* * *}$ & & & & & & & & & & \\
\hline \multirow[t]{2}{*}{ PL_DD*FI } & & 0.025 & & & 0.024 & & & & & & \\
\hline & & $(2.618)^{* * *}$ & & & $(2.135)^{* *}$ & & & & & & \\
\hline \multirow[t]{2}{*}{ TL_DD*FI } & & & 0.02 & & & & 0.021 & & & 0.029 & \\
\hline & & & $(2.347)^{* *}$ & & & & $(1.919)^{*}$ & & & $(3.476) * * *$ & \\
\hline \multirow[t]{2}{*}{ PL_TF*FI } & & & & 0.017 & & & & & 0.033 & & 0.02 \\
\hline & & & & $(4.273)^{* * *}$ & & & & & $(4.090)^{* * *}$ & & $(1.837)^{*}$ \\
\hline \multirow[t]{2}{*}{$\mathrm{PL}_{\mathrm{fi}} \mathrm{PL} * \mathrm{FI}$} & & & & & 0.024 & 0.022 & 0.068 & 0.023 & 0.011 & 0.013 & 0.008 \\
\hline & & & & & $(2.452)^{* *}$ & $(1.985)^{* *}$ & $(2.314)^{* *}$ & $(2.051)^{* *}$ & $(2.654)^{* * *}$ & $(1.471)$ & $(1.846)^{*}$ \\
\hline \multirow[t]{2}{*}{ PL_TL*FI } & & & & & & 0.009 & & & & 0.007 & \\
\hline & & & & & & $(1.916)^{*}$ & & & & $(1.720)^{*}$ & \\
\hline \multirow[t]{2}{*}{ TF_DD*FI } & & & & & & & & 0.015 & & & 0.011 \\
\hline & & & & & & & & $(4.460)^{* * *}$ & & & $(2.320)^{* *}$ \\
\hline \multirow[t]{2}{*}{ OPP*FI } & 0.012 & 0.012 & 0.012 & 0.012 & 0.011 & 0.011 & 0.011 & 0.011 & 0.012 & 0.012 & 0.012 \\
\hline & $(5.857)^{* * *}$ & $(5.626)^{* * *}$ & $(5.838) * * *$ & $(5.842)^{* * *}$ & $(5.437)^{* * *}$ & $(5.437)^{* * *}$ & $(5.380)^{* * *}$ & $(5.492)^{* * *}$ & $(5.578)^{* * *}$ & $(5.570)^{* * *}$ & $(5.564)^{* * *}$ \\
\hline $\mathrm{R}^{2}$-adj & 0.184 & 0.184 & 0.184 & 0.187 & 0.186 & 0.185 & 0.185 & 0.186 & 0.191 & 0.188 & 0.186 \\
\hline Obs & 1864 & 1928 & 1920 & 1864 & 1925 & 1920 & 1920 & 1864 & 1864 & 1920 & 1864 \\
\hline
\end{tabular}


Table 5. Robustness Tests for Effects of Fund Utilization Efficiency and Growth Opportunities on Finance-growth Nexus in 22 Developed Countries.

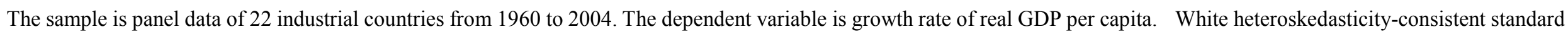
errors and covariance are used; the $\mathrm{t}$-values are in parentheses. $* * *, * *$, and $*$ denote significance at level of $1 \%, 5 \%$, and $10 \%$, respectively.

\begin{tabular}{|c|c|c|c|c|c|c|c|c|c|c|c|}
\hline Model & 1 & 2 & 3 & 4 & 5 & 6 & 7 & 8 & 9 & 10 & 11 \\
\hline \multirow[t]{2}{*}{ INIY } & -0.006 & -0.008 & -0.008 & -0.006 & -0.008 & -0.008 & -0.008 & -0.006 & -0.006 & -0.008 & -0.006 \\
\hline & $(0.00)$ & $(0.00)$ & $(0.00)$ & $(0.00)$ & $(0.00)$ & $(0.00)$ & $(0.00)$ & $(0.00)$ & $(0.00)$ & $(0.00)$ & $(0.00)$ \\
\hline \multirow[t]{2}{*}{ INIH } & -0.007 & -0.009 & -0.009 & -0.007 & -0.009 & -0.009 & -0.009 & -0.007 & -0.007 & -0.009 & -0.007 \\
\hline & $(0.00)$ & $(0.00)$ & $(0.00)$ & $(0.00)$ & $(0.00)$ & $(0.00)$ & $(0.00)$ & $(0.00)$ & $(0.00)$ & $(0.00)$ & $(0.00)$ \\
\hline \multirow[t]{2}{*}{ GOVY } & -0.349 & -0.338 & -0.338 & -0.356 & -0.354 & -0.337 & -0.35 & -0.347 & -0.373 & -0.337 & -0.38 \\
\hline & $(-9.327)^{* * *}$ & $(-9.459)^{* * *}$ & $(-9.502) * * *$ & $(-9.448)^{* * *}$ & $(-9.676)^{* * *}$ & $(-9.448) * * *$ & $(-9.639)^{* * *}$ & $(-9.165) * * *$ & $(-9.656)^{* * *}$ & $(-9.582)^{* * *}$ & $(-9.781)^{* * *}$ \\
\hline \multirow[t]{2}{*}{ EXIMY } & 0.026 & 0.025 & 0.028 & 0.027 & 0.029 & 0.031 & 0.031 & 0.026 & 0.032 & 0.032 & 0.034 \\
\hline & $(2.988)^{* * *}$ & $(2.930)^{* * *}$ & $(3.269)^{* * *}$ & $(3.074)^{* * *}$ & $(3.402)^{* * *}$ & $(3.634) * * *$ & $(3.543)^{* * *}$ & $(3.023)^{* * *}$ & $(3.601)^{* * *}$ & $(3.725)^{* * *}$ & $(3.740)^{* * *}$ \\
\hline \multirow[t]{2}{*}{ CPIG } & -0.234 & -0.234 & -0.229 & -0.233 & -0.241 & -0.243 & -0.241 & -0.245 & -0.247 & -0.242 & -0.251 \\
\hline & $(-10.959)^{* * *}$ & $(-10.787)^{* * *}$ & $(-10.841)^{* * *}$ & $(-10.974)^{* * *}$ & $(-10.953)^{* * *}$ & $(-11.087)^{* * *}$ & $(-11.197)^{* * *}$ & $(-11.231)^{* * *}$ & $(-11.402)^{* * *}$ & $(-11.119)^{* * *}$ & $(-11.531)^{* * *}$ \\
\hline \multirow[t]{2}{*}{ CRISIS } & -0.012 & -0.01 & -0.01 & -0.01 & -0.01 & -0.012 & -0.01 & -0.01 & -0.01 & -0.012 & -0.009 \\
\hline & $(-4.259)^{* * *}$ & $(-3.351)^{* * *}$ & $(-3.610)^{* * *}$ & $(-3.682)^{* * *}$ & $(-4.006)^{* * *}$ & $(-4.442)^{* * *}$ & $(-3.611)^{* * *}$ & $(-3.811)^{* * *}$ & $(-3.659)^{* * *}$ & $(-4.252)^{* * *}$ & $(-3.413) * * *$ \\
\hline \multirow[t]{2}{*}{ FI } & -0.025 & -0.022 & -0.021 & -0.026 & -0.023 & -0.035 & -0.022 & -0.028 & -0.026 & -0.03 & -0.079 \\
\hline & $(-6.472)^{* * *}$ & $(-5.463)^{* * *}$ & $(-5.399)^{* * *}$ & $(-6.787)^{* * *}$ & $(-5.940)^{* * *}$ & $(-7.887)^{* * *}$ & $(-5.640)^{* * *}$ & $(-6.685)^{* * *}$ & $(-6.875)^{* * *}$ & $(-6.889)^{* * *}$ & $(-2.657)^{* * *}$ \\
\hline \multirow[t]{2}{*}{$\mathrm{PL}_{\mathrm{fi} \_\mathrm{DD}} \mathrm{FI}$} & 0.006 & & & & & & & & & & \\
\hline & $(2.003)^{* *}$ & & & & & & & & & & \\
\hline \multirow[t]{2}{*}{ PL_DD*FI } & & 0.007 & & & 0.053 & & & & & & \\
\hline & & -1.565 & & & $(4.034)^{* * *}$ & & & & & & \\
\hline \multirow[t]{2}{*}{ TL_DD*FI } & & & 0.016 & & & & 0.047 & & & 0.051 & \\
\hline & & & $(3.779)^{* * *}$ & & & & $(3.601)^{* * *}$ & & & $(3.842)^{* * *}$ & \\
\hline \multirow[t]{2}{*}{ PL_TF*FI } & & & & 0.007 & & & & & 0.058 & & 0.059 \\
\hline & & & & $(2.905)^{* * *}$ & & & & & $(4.271)^{* * *}$ & & $(4.367)^{* * *}$ \\
\hline \multirow[t]{2}{*}{$\mathrm{PL}_{\mathrm{fi}} \mathrm{PL}^{*} \mathrm{FI}$} & & & & & 0.02 & 0.059 & 0.013 & 0.055 & 0.007 & 0.013 & 0.007 \\
\hline & & & & & $(2.341)^{* *}$ & $(4.610)^{* * *}$ & $(3.097)^{* * *}$ & $(4.050) * * *$ & $(2.910)^{* * *}$ & $(3.056) * * *$ & $(2.929)^{* * *}$ \\
\hline \multirow[t]{2}{*}{ PL_TL*FI } & & & & & & 0.012 & & & & 0.011 & \\
\hline & & & & & & $(4.562)^{* * *}$ & & & & $(4.209)^{* * *}$ & \\
\hline \multirow[t]{2}{*}{ TF_DD*FI } & & & & & & & & 0.009 & & & 0.052 \\
\hline & & & & & & & & $(2.680)^{* * *}$ & & & $(1.785)^{*}$ \\
\hline \multirow[t]{2}{*}{ OPP*FI } & 0.009 & 0.009 & 0.008 & 0.009 & 0.009 & 0.009 & 0.009 & 0.009 & 0.009 & 0.009 & 0.009 \\
\hline & $(4.599)^{* * *}$ & $(4.533)^{* * *}$ & $(4.299)^{* * *}$ & $(4.324)^{* * *}$ & $(4.456)^{* * *}$ & $(4.814) * * *$ & $(4.372) * * *$ & $(4.583) * * *$ & $(4.381)^{* * *}$ & $(4.655) * * *$ & $(4.426)^{* * *}$ \\
\hline $\mathrm{R}^{2}$-adj & 0.391 & 0.394 & 0.401 & 0.394 & 0.403 & 0.414 & 0.406 & 0.400 & 0.403 & 0.418 & 0.405 \\
\hline Obs & 797 & 809 & 809 & 797 & 809 & 809 & 809 & 797 & 797 & 809 & 797 \\
\hline
\end{tabular}


Table 6. Robustness Tests for Effects of Fund Utilization Efficiency And Growth Opportunities on Finance-growth Nexus in 27 Developing Countries.

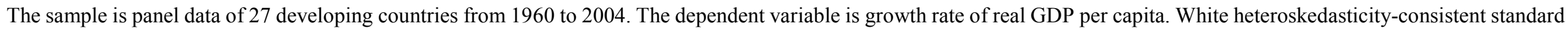
errors and covariance are used; the t-values are in parentheses. $* * *, * *$, and $*$ denote significance at level of $1 \%, 5 \%$, and $10 \%$, respectively.

\begin{tabular}{|c|c|c|c|c|c|c|c|c|c|c|c|}
\hline Model & 1 & 2 & 3 & 4 & 5 & 6 & 7 & 8 & 9 & 10 & 11 \\
\hline \multirow[t]{2}{*}{ INIY } & 0.003 & 0.005 & 0.001 & 0.002 & 0.006 & 0.001 & 0.001 & 0.002 & 0.002 & 0.001 & 0.002 \\
\hline & $(0.00)$ & $(0.00)$ & $(0.00)$ & $(0.00)$ & $(0.00)$ & $(0.00)$ & $(0.00)$ & $(0.00)$ & $(0.00)$ & $(0.00)$ & $(0.00)$ \\
\hline \multirow[t]{2}{*}{ INIH } & -0.026 & -0.024 & -0.023 & -0.026 & -0.029 & -0.023 & -0.023 & -0.026 & -0.026 & -0.023 & -0.026 \\
\hline & $(0.00)$ & $(0.00)$ & $(0.00)$ & $(0.00)$ & $(0.00)$ & $(0.00)$ & $(0.00)$ & $(0.00)$ & $(0.00)$ & $(0.00)$ & $(0.00)$ \\
\hline \multirow[t]{2}{*}{ GOVY } & -0.144 & -0.147 & -0.138 & -0.156 & -0.131 & -0.128 & -0.124 & -0.151 & -0.143 & -0.143 & -0.155 \\
\hline & $(-3.312)^{* * *}$ & $(-3.440)^{* * *}$ & $(-3.223)^{* * *}$ & $(-3.571)^{* * *}$ & $(-3.085)^{* * *}$ & $(-3.004) * * *$ & $(-2.883) * * *$ & $(-3.474)^{* * *}$ & $(-3.260) * * *$ & $(-3.365)^{* * *}$ & $(-3.548) * * *$ \\
\hline \multirow[t]{2}{*}{ EXIMY } & 0.006 & 0.009 & 0.008 & 0.005 & 0.006 & 0.004 & 0.006 & 0.003 & 0.002 & 0.006 & 0.003 \\
\hline & $(0.734)$ & $(1.044)$ & $(0.962)$ & $(0.637)$ & $(0.657)$ & $(0.546)$ & $(0.683)$ & $(0.335)$ & $(0.230)$ & $(0.758)$ & $(0.367)$ \\
\hline \multirow[t]{2}{*}{ CPIG } & -0.002 & -0.002 & -0.002 & -0.002 & -0.002 & -0.002 & -0.002 & -0.002 & -0.002 & -0.002 & -0.002 \\
\hline & $(-2.595) * * *$ & $(-2.614)^{* * *}$ & $(-2.636)^{* * *}$ & $(-2.609)^{* * *}$ & $(-2.628)^{* * *}$ & $(-2.663)^{* * *}$ & $(-2.636)^{* * *}$ & $(-2.621)^{* * *}$ & $(-2.623)^{* * *}$ & $(-2.640)^{* * *}$ & $(-2.608)^{* * *}$ \\
\hline \multirow[t]{2}{*}{ CRISIS } & -0.026 & -0.026 & -0.026 & -0.026 & -0.025 & -0.025 & -0.024 & -0.027 & -0.025 & -0.026 & -0.026 \\
\hline & $(-5.483) * * *$ & $(-5.759) * * *$ & $(-5.627)^{* * *}$ & $(-5.492) * * *$ & $(-5.657)^{* * *}$ & $(-5.610) * * *$ & $(-5.474) * * *$ & $(-5.751)^{* * *}$ & $(-5.367) * * *$ & $(-5.781)^{* * *}$ & $(-5.588)^{* * *}$ \\
\hline \multirow[t]{2}{*}{ FI } & -0.055 & -0.032 & -0.035 & -0.032 & -0.055 & -0.061 & -0.056 & -0.036 & -0.059 & -0.033 & -0.034 \\
\hline & $(-4.410) * * *$ & $(-3.219) * * *$ & $(-3.342)^{* * *}$ & $(-3.154)^{* * *}$ & $(-3.520)^{* * *}$ & $(-4.008) * * *$ & $(-3.535) * * *$ & $(-3.508)^{* * *}$ & $(-3.813)^{* * *}$ & $(-3.335)^{* * *}$ & $(-3.383) * * *$ \\
\hline \multirow[t]{2}{*}{$\mathrm{PL}_{\mathrm{fi}} \mathrm{DD}$ FI } & 0.032 & & & & & & & & & & \\
\hline & $(3.629)^{* * *}$ & & & & & & & & & & \\
\hline \multirow[t]{2}{*}{ PL_DD*FI } & & 0.032 & & & 0.03 & & & & & & \\
\hline & & $(2.397)^{* *}$ & & & $(1.959)^{*}$ & & & & & & \\
\hline \multirow[t]{2}{*}{ TL_DD*FI } & & & 0.038 & & & & 0.031 & & & 0.031 & \\
\hline & & & $(2.167)^{* *}$ & & & & $(2.071)^{* *}$ & & & $(2.211)^{* *}$ & \\
\hline \multirow[t]{2}{*}{ PL_TF*FI } & & & & 0.043 & & & & & 0.034 & & 0.026 \\
\hline & & & & $(3.202)^{* * *}$ & & & & & $(2.245)^{* *}$ & & $(1.831)^{*}$ \\
\hline \multirow[t]{2}{*}{$\mathrm{PL}_{\mathrm{fi}-\mathrm{PL}} \mathrm{PI}$} & & & & & 0.112 & 0.036 & 0.031 & 0.035 & 0.043 & 0.037 & 0.04 \\
\hline & & & & & $(1.455)$ & $(2.446)^{* *}$ & $(2.290)^{* *}$ & $(2.363)^{* *}$ & $(3.182)^{* * *}$ & $(2.714)^{* * *}$ & $(2.952)^{* * *}$ \\
\hline \multirow[t]{2}{*}{ PL_TL*FI } & & & & & & 0.033 & & & & 0.039 & \\
\hline & & & & & & $(3.373)^{* * *}$ & & & & $(3.241)^{* * *}$ & \\
\hline \multirow[t]{2}{*}{ TF_DD*FI } & & & & & & & & 0.02 & & & 0.024 \\
\hline & & & & & & & & $(2.071)^{* *}$ & & & $(2.279)^{* *}$ \\
\hline \multirow[t]{2}{*}{ OPP*FI } & 0.027 & 0.025 & 0.026 & 0.027 & 0.023 & 0.023 & 0.024 & 0.022 & 0.026 & 0.022 & 0.025 \\
\hline & $(4.118)^{* * *}$ & $(3.764)^{* * *}$ & $(3.842)^{* * *}$ & $(3.998)^{* * *}$ & $(3.617)^{* * *}$ & $(3.548)^{* * *}$ & $(3.764)^{* * *}$ & $(3.428)^{* * *}$ & $(3.998)^{* * *}$ & $(3.396)^{* * *}$ & $(3.689) * * *$ \\
\hline $\mathrm{R}^{2}$-adj & 0.183 & 0.172 & 0.171 & 0.181 & 0.176 & 0.18 & 0.176 & 0.177 & 0.186 & 0.186 & 0.184 \\
\hline Obs & 848 & 896 & 889 & 848 & 893 & 889 & 889 & 848 & 848 & 889 & 848 \\
\hline
\end{tabular}


Table 7. Robustness Tests with the Model Subsuming Stock Market Variable

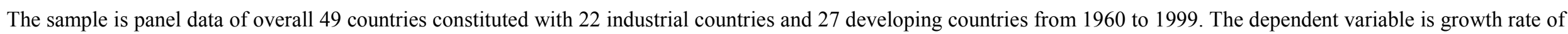

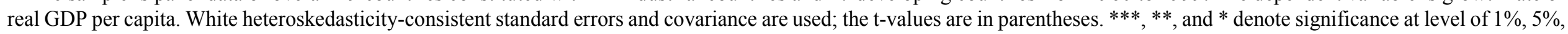
and $10 \%$, respectively.

\begin{tabular}{|c|c|c|c|c|c|c|c|c|c|c|c|}
\hline Model & 1 & 2 & 3 & 4 & 5 & 6 & 7 & 8 & 9 & 10 & 11 \\
\hline \multirow[t]{2}{*}{ INIY } & 0.002 & 0.002 & 0.002 & 0.002 & 0.002 & 0.002 & 0.002 & 0.002 & 0.002 & 0.002 & 0.002 \\
\hline & $(0.00)$ & $(0.00)$ & $(0.00)$ & $(0.00)$ & $(0.00)$ & $(0.00)$ & $(0.00)$ & $(0.00)$ & $(0.00)$ & $(0.00)$ & $(0.00)$ \\
\hline \multirow[t]{2}{*}{$\mathrm{INIH}$} & 0.008 & 0.007 & 0.007 & 0.008 & 0.007 & 0.007 & 0.007 & 0.009 & 0.009 & 0.007 & 0.009 \\
\hline & $(0.00)$ & $(0.00)$ & $(0.00)$ & $(0.00)$ & $(0.00)$ & $(0.00)$ & $(0.00)$ & $(0.00)$ & $(0.00)$ & $(0.00)$ & $(0.00)$ \\
\hline \multirow[t]{2}{*}{ GOVY } & -0.149 & -0.16 & -0.148 & -0.165 & -0.168 & -0.159 & -0.159 & -0.162 & -0.172 & -0.152 & -0.159 \\
\hline & $(-2.641)^{* * *}$ & $(-2.848)^{* * *}$ & $(-2.634)^{* * *}$ & $(-2.904)^{* * *}$ & $(-2.975)^{* * *}$ & $(-2.827)^{* * *}$ & $(-2.848) * * *$ & $(-2.865)^{* * *}$ & $(-3.047) * * *$ & $(-2.704)^{* * *}$ & $(-2.795)^{* * *}$ \\
\hline \multirow[t]{2}{*}{ EXIMY } & 0.01 & 0.009 & 0.009 & 0.006 & 0.008 & 0.006 & 0.007 & 0.006 & 0.005 & 0.007 & 0.004 \\
\hline & -0.788 & -0.725 & -0.754 & -0.533 & -0.687 & -0.481 & -0.624 & -0.534 & -0.396 & -0.561 & -0.334 \\
\hline \multirow[t]{2}{*}{ CPIG } & -0.002 & -0.002 & -0.002 & -0.002 & -0.002 & -0.002 & -0.002 & -0.002 & -0.002 & -0.002 & -0.002 \\
\hline & $(-2.460)^{* *}$ & $(-2.477)^{* *}$ & $(-2.474)^{* *}$ & $(-2.485)^{* *}$ & $(-2.479)^{* *}$ & $(-2.478)^{* *}$ & $(-2.474)^{* *}$ & $(-2.465)^{* *}$ & $(-2.484)^{* *}$ & $(-2.469)^{* *}$ & $(-2.459)^{* *}$ \\
\hline \multirow[t]{2}{*}{ CRISIS } & -0.02 & -0.02 & -0.02 & -0.019 & -0.02 & -0.02 & -0.02 & -0.02 & -0.02 & -0.02 & -0.02 \\
\hline & $(-5.942)^{* * *}$ & $(-6.174)^{* * *}$ & $(-6.009)^{* * *}$ & $(-5.719)^{* * *}$ & $(-6.188)^{* * *}$ & $(-6.186)^{* * *}$ & $(-6.178)^{* * *}$ & $(-5.986)^{* * *}$ & $(-5.876)^{* * *}$ & $(-6.124)^{* * *}$ & $(-5.783)^{* * *}$ \\
\hline \multirow[t]{2}{*}{ FI } & -0.022 & -0.015 & -0.016 & -0.019 & -0.016 & -0.029 & -0.017 & -0.019 & -0.018 & -0.027 & -0.019 \\
\hline & $(-3.032)^{* * *}$ & $(-2.176)^{* *}$ & $(-2.330)^{* *}$ & $(-2.640)^{* * *}$ & $(-2.309)^{* *}$ & $(-3.277)^{* * *}$ & $(-2.488)^{* *}$ & $(-2.694)^{* * *}$ & $(-2.634)^{* * *}$ & $(-3.146)^{* * *}$ & $(-2.624)^{* * *}$ \\
\hline \multirow[t]{2}{*}{$\mathrm{PL}_{\mathrm{fi} \_} \mathrm{DD} * \mathrm{FI}$} & 0.013 & & & & & & & & & & \\
\hline & $(2.818)^{* * *}$ & & & & & & & & & & \\
\hline \multirow[t]{2}{*}{ PL_DD*FI } & & 0.036 & & & 0.048 & & & & & & \\
\hline & & $(2.764)^{* * *}$ & & & $(3.275)^{* * *}$ & & & & & & \\
\hline \multirow[t]{2}{*}{ TL_DD*FI } & & & 0.021 & & & & 0.049 & & & 0.040 & \\
\hline & & & $(1.956)^{*}$ & & & & $(3.246)^{* * *}$ & & & $(3.791)^{* * *}$ & \\
\hline \multirow[t]{2}{*}{ PL_TF*FI } & & & & 0.026 & & & & & 0.045 & & 0.023 \\
\hline & & & & $(4.108)^{* * *}$ & & & & & $(3.096)^{* * *}$ & & $(1.451)$ \\
\hline \multirow{2}{*}{$\mathrm{PL}_{\mathrm{fi} \_} \mathrm{PL} * \mathrm{FI}$} & & & & & 0.019 & 0.041 & 0.024 & 0.048 & 0.02 & 0.024 & 0.01 \\
\hline & & & & & $(1.899)^{*}$ & $(3.903)^{* * *}$ & $(2.249)^{* *}$ & $(3.235)^{* * *}$ & $(3.654)^{* * *}$ & $(2.127)^{* *}$ & $(2.105)^{* *}$ \\
\hline \multirow[t]{2}{*}{ PL_TL*FI } & & & & & & 0.014 & & & & 0.013 & \\
\hline & & & & & & $(2.179)^{* *}$ & & & & $(1.933)^{*}$ & \\
\hline \multirow[t]{2}{*}{ TF_DD*FI } & & & & & & & & 0.022 & & & 0.016 \\
\hline & & & & & & & & $(3.279)^{* * *}$ & & & $(2.142)^{* *}$ \\
\hline \multirow[t]{2}{*}{ OPP*FI } & 0.013 & 0.012 & 0.012 & 0.014 & 0.011 & 0.012 & 0.011 & 0.012 & 0.012 & 0.012 & 0.013 \\
\hline & $(4.217)^{* * *}$ & $(4.033)^{* * *}$ & $(4.124)^{* * *}$ & $(4.490)^{* * *}$ & $(3.834)^{* * *}$ & $(4.170)^{* * *}$ & $(3.959)^{* * *}$ & $(4.011)^{* * *}$ & $(4.223)^{* * *}$ & $(4.276)^{* * *}$ & $(4.190)^{* * *}$ \\
\hline \multirow[t]{2}{*}{ STOCK } & 0.001 & 0.001 & 0.001 & 0.001 & 0.001 & 0.001 & 0.001 & 0.001 & 0.001 & 0.001 & 0.001 \\
\hline & $(1.827)^{*}$ & $(1.849)^{*}$ & $(1.614)$ & $(1.797)^{*}$ & $(1.673)^{*}$ & $(1.754)^{*}$ & -1.577 & $(1.747)^{*}$ & $(1.790)^{*}$ & $(1.587)$ & $(1.802)^{*}$ \\
\hline $\mathrm{R}^{2}$-adj & 0.22 & 0.227 & 0.222 & 0.226 & 0.238 & 0.238 & 0.238 & 0.231 & 0.237 & 0.24 & 0.218 \\
\hline Obs & 897 & 918 & 918 & 897 & 918 & 918 & 918 & 897 & 897 & 918 & 897 \\
\hline
\end{tabular}




\section{Conclusions}

This paper establishes seven indicators of funds utilization efficiency and one indicator of growth opportunities to empirically examine the impacts of funds utilization efficiency and growth opportunities on finance-growth nexus for 49 countries from 1960 to 2004.

The results show that funds utilization efficiency, both of asset and liability allocation efficiency, and growth opportunities predominate in the effects of financial intermediaries on economic growth. Furthermore, this paper finds that predominance of funds utilization efficiency and growth opportunities in finance-growth nexus exists in both of developed and developing countries. In addition, it is more potent in developing countries than in developed countries. Financial intermediaries who utilize funds efficiently and encounter fine growth opportunities promote economic growth more in developing countries than in developed countries. Finally, the empirical results are robust to discontinuity caused by operation of European Monetary Unification (EMU), and to models subsuming stock market measure.

In summary, the empirical findings in this study not only support the assertions this paper advances, but also clarify the controversies over finance-growth nexus in previous empirical studies. Firstly, finance-growth is not monotonic. Secondly, it is funds utilization efficiency and growth opportunities are the crucial to finance-growth nexus, rather than income levels (De Gregorio and Guidotti,1995; Rioja and Valev,2003; Shen and Lee,2006) or levels of financial development (Levine et al.,2000; Rioja and Valev,2004; Chen,2008) do. Finally, the results of this study imply governments should formulate policies to enhance funds utilization efficiency and growth opportunities rather than to just monotonically promote financial development or income levels.

\section{Appendix}

Table A1. List of Sample Countries

\begin{tabular}{|c|c|c|c|c|}
\hline U.S.A. & U.K. & Austria & Belgium & Denmark \\
\hline France & Germany & Italy & Norway & Sweden \\
\hline Switzerland & Luxembourg & Netherlands & Finland & Greece \\
\hline Ireland & Canada & Japan & Australia & New-Zealand \\
\hline Portugal & Spain & South-Africa & Argentina & Chile \\
\hline Venezuela & Colombia & Mexico & Brazil & Uruguay \\
\hline Egypt & Jamaica & $\begin{array}{c}\text { Trinidad and } \\
\text { Tobago }\end{array}$ & Peru & Malaysia \\
\hline Sri-Lanka & India & Israel & Jordan & Kenya \\
\hline Pakistan & Philippines & Indonesia & Korea, Rep. & Morocco \\
\hline Nigeria & Singapore & Thailand & Tunisia & \\
\hline
\end{tabular}

\section{REFERENCES}

[1] Arestis, P, Demetriades, PO \& Luintel, KB 2001, 'Financial Development and Economic Growth: The Role of Stock Markets', Journal of Money, Credit and Financial intermediarying, vol. 33, pp. 16-41.

[2] Beck, T \& Levine, R 2004, 'Stock Markets, Financial intermediarys, and Growth: Panel Evidence', Journal of Financial intermediary and Finance, vol. 28, pp. 423-442.

[3] Beck, T, Levine, R \& Loayza, N 2000, 'Finance and the sources of growth', Journal of Financial Economics, vol. 58, pp. 261-300.

[4] Bencivenga, V \& Smith, BD 1991, 'Financial Intermediation and Endogenous Growth', The Review of Economic Studies, vol. 58, pp. 195-209.

[5] Bencivenga, V, Smith, BD \& Starr, RM 1995, 'Transaction Cost, Technological Choice, and Endogeneous Growth', Journal of Economic Theory, vol. 67, pp. 53-117.

[6] Blackburn, K \& Hung, VTY 1998, 'A Theory of Growth, Financial Development and Trade', Economica, vol. 65, pp. 107-124.

[7] Bose, N \& Cothren, R 1997, 'Asymmetric information and loan contracts in a neoclassical growth model', Journal of Money, Credit, and Banking, vol. 29, pp. 423-439.

[8] Boyd, J \& Prescott, E 1986, 'Financial intermediary-coalition s', Journal of Economic Theory, vol. 38, pp. 211-232.

[9] Chang, PC, Jia, C \& Wang, Z 2010, 'Bank fund reallocation and economic growth: Evidence from China', Journal of Banking and Finance, vol. 34, pp. 2753-2766.

[10] Chen, CR 2008, 'Financial Development and Economic Growth: The Theoretical Model and Empirical Evidence', Unpublished dissertation of National Chung Cheng University, Taiwan.

[11] De Gregorio, J \& Guidotti, PE 1995, 'Financial Development and Economic rowth', World Development, vol. 233, pp. 433-448.

[12] Deidda, L \& Fattouh, B 2002, 'Nonlinearity between Finance and Growth', Economics Letters, vol. 74, pp. 339-345.

[13] Demetriades, P \& Hussein, K 1996, 'Does Financial Development Cause Economic Growth?', Journal of Development Economics, vol. 51, pp. 385-409.

[14] Diamond, D 1984, 'Financial Intermediation and Delegated Monitoring', Review of Economic Studies, vol. 51, pp. 393-414.

[15] Goldsmith, RW 1969, 'Finance Structure and Development', Yale University Press, New Haven, CT.

[16] Greenwood, J \& Jovanovic, B 1990, 'Financial Development, Growth, and the Distribution of Income', Journal of Political Economy, vol. 98, pp. 1076-1107.

[17] Greenwood, J \& Smith, B 1997, 'Financial Market in Development, and the Development of Financial Markets', Journal of Economic Dynamic and Control, vol. 21, pp. 145-186. 
[18] Herring, RJ \& Vankudre P 1987, 'Growth Opportunities and Risk-Taking by Financial Intermediaries', Journal of Finance, vol. 42, pp. 583-599.

[19] King, R \& Levine, R 1993a, 'Finance and growth: Schumpeter might be right', Quarterly Journal of Economics, vol. 108, pp. 717-738.

[20] King, R \& Levine, R 1993b, 'Finance, entrepreneurship, and growth: theory and evidence', Journal of Monetary Economics, vol. 32, pp. 513-542.

[21] La Porta, R, Lopez-De-Silanes, F \& Shleifer, A 2002, 'Government Ownership of Banks', Journal of Finance, vol. 57, pp. 265-301.

[22] Levine, $\mathrm{R}$ 2002, 'Financial intermediary-Based or Market-Based Financial Systems: Which Is Better?', Journal of Financial Intermediation, vol. 11, pp. 398-428.

[23] Levine, R \& Zervos, S 1998, 'Stock Markets, Banks, and Economic Growth', American Economic Review, vol. 88, pp. $537-558$.

[24] Levine, R, Loayza, N \& Beck, T 2000, 'Financial intermediation and growth: Causality and causes', Journal of Monetary Economics, vol. 46, pp. 31-77.

[25] Loayza, N \& Ranciere, R 2004, 'Financial fragility, financial development, and growth', Unpublished working paper.

[26] McKinnon, RI 1973, 'Money and Capital in Economic Development', Washington: Brookings Institute.
[27] Pagano, M 1993, 'Financial Markets and Growth: An Overview', European Economic Review, vol. 37, pp. 613-22.

[28] Rajan, R \& Zingales, L 1998, 'Financial Dependence and Growth', American Economic Review, vol. 88, pp. 559-586.

[29] Ranciere, R, Tronell, A \& Westermann, F 2006, 'Decomposing the Effects of Financial Liberalization: Crises vs. Growth', Journal of Banking and Finance, vol. 30, pp. 331-3348.

[30] Rioja, F \& Valev, N 2003, 'Finance and sources of growth at various stages of economic development', Economic Inquiry, vol. 42 , pp. 127-140.

[31] Rioja, F \& Valev, N 2003, 'Does one size fit all? : A reexamination of the finance and growth relationship', Journal of Development Economics, vol. 74, pp. 429-447.

[32] Rousseau, PL \& Wachtel, P 2000, 'Equity Market and Growth: Cross-country Evidence on Timing and Outcomes, 1980-1995', Journal of Banking and Finance, vol. 24, pp. 1933-1957.

[33] Rousseau, P \& Wachtel, P 2002, 'Inflation Thresholds and The Finance-growth Nexus', Journal of International Money and Finance, vol. 21, pp. 777-93.

[34] Shaw, ES 1973, 'Financial Deepening in Economic Development', New York: Oxford University Press.

[35] Shen, CH \& Lee, CC 2006, 'Same Financial Development yet Different Economic growth-Why?', Journal of Money, Credit, and Banking, vol. 38, pp. 1908-1944.

\section{Endnotes}

\footnotetext{
i See Boyd and Prescott, 1986; Greenwood and Jovanovic, 1990; Bencivenga and Smith, 1991; Pagano, 1993; King and Levine, $1993 \mathrm{~b}$

ii See King and Levine, 1993a; De Gregorio and Guidotti, 1995; Levine and Zervos, 1998; Beck et al., 2000; Levine et al., 2000; Rousseau and Wachtel, 2000; Rioja and Valev, 2003; Beck and Levine, 2004.

La Porta et al. (2002) and Chang et al. (2010) have similar finding, though they focus on the funds inefficiency caused by the high level of government ownership and do not directly examine the impacts of funds inefficiency on finance-growth nexus.

See Hutchison and McDill, 1999; McDill, 2000; Eichengreen, 2002; Nutchison and Noy, 2005; Boyd et al., 2005; Shen and Lee, 2006; Ranciere et al., 2006 .

Similarly, Levine (1991), Saint- Paul (1992), Obstfeld (1994), Bencivenga et al. (1995), Greenwood and Smith (1997) develop theoretical models to demonstrate the stock market provide the functions of risk sharing and wider diversification of portfolios, and thus direct resources towards longer-run, less liquid but higher-yield investment projects. Thus they conclude that stock market is conducive to ameliorate allocated efficiency of funds and economic growth.

The sampling criteria in this study are as follows. Because the stock market data is available beginning in 1975 and more complete after 1980 , to obtain the maximum sample possible, this study establishes sampling criteria, first, based on the period 1980-2004. This study deletes those countries missing stock market indicator data for more than ten years, and then deles those countries missing data of financial intermediation indicators and control variables in continuous periods over 1980-2004.

VIII The measure is used in Beck et al.(2000), Rioja and Valev (2003).

viii See Levine (1991), Bencivenga et al. (1995), Boyd and Smith (1998), Beck and Levine (2004), Shen and Lee (2006), Chen (2008).

ix The empirical results when employing growth rate of total loan (LG) as growth opportunities are quite similar to the one employing growth rate of net loan(NLG), and thus only reporting the posterior
} 